\title{
'Det er helt i orden': Kulturelle shibboletter i jobsamtaler med andetsprogsbrugere af dansk
}

\author{
MARTA KIRILOVA
}

\begin{abstract}
I denne artikel analyserer jeg datauddrag fra to jobinterview hvor ansøgerne taler dansk som andetsprog. Data stammer fra et integrationsinitiativ i Danmark hvis formål var at få flygtninge og indvandrere i arbejde. Jeg anvender en sprogideologisk ramme i analyserne (Silverstein 1985, Irvine og Gal 2000) som jeg operationaliserer igennem begreberne dorvogtning, medlemskabstilskrivninger og shibboletter. Jeg fokuserer særligt på shibboletter som et indeks for sprogligt og kulturelt tilhørsforhold og ser nærmere på shibboletter i forhold til to områder: konventionelle udtryk som shibboletter og emnemassige fallesskaber som shibboletter. I analysen viser jeg at såvel brugen af konventionelle udtryk som etableringen af emnemæssige fællesskaber hjælper både ansøgere og ansættelsesudvalg med at forhandle et momentant fællesskab. Hvis ansøgeren kan placere sig i dette fællesskab, bliver vedkommende også vurderet som egnet til det ansøgte job. Jeg diskuterer endvidere relationen mellem sprogbrug og kulturel anerkendelse. Jeg foreslår at brugen af konventionelle udtryk er særligt interessant i flersproget kommunikation, og at sådanne udtryk muligvis vil kunne fungere som en succesfuld kommunikationsstrategi når andetsprogsbrugere på begynderniveau omgås med sprogbrugere på et mere avanceret sprogligt niveau.
\end{abstract}

EMNEORD: shibboletter, dørvogtning, jobsamtaler, dansk som andetsprog, kulturelt medlemskab

\section{INTRODUKTION}

De seneste år er der i Danmark foretaget en række specifikke tiltag med henblik på at forbedre flygtninge og indvandreres muligheder for at lære dansk på arbejdspladsen. Arbejdsmarkedsdansk, sprogpraktikker og sprogmentorprogrammer er blandt de initiativer hvor formel sprogundervisning styrkes (eller somme tider erstattes helt) af samta- 
ler med kolleger om arbejdsrelaterede opgaver. Fra politisk side er der bred enighed om at det danske sprog er vejen til arbejde og integration. De nytilkomne forventes at blive 'gode' til dansk for at kunne yde en tilfredsstillende arbejdsindsats og indgå i det danske samfund. Fra et sociolingvistisk synspunkt er det dog indlysende at det der tæller som 'godt' dansk på de enkelte arbejdspladser, ikke kan defineres uafhængigt af tid, sted, formål, holdninger og samtalepartnere.

I denne artikel ser jeg nærmere på et integrationsinitiativ som Københavns Kommune udførte i 2006-2016 med det formål at gøre det muligt for flygtninge og indvandrere at få adgang til jobmarkedet $\mathrm{i}$ Danmark. Initiativet gik under navnet 'Integrations- og Oplæringsstillinger' (IO-stillinger). IO-stillingerne var en særordning tiltænkt personer med udenlandsk baggrund som primært på grund af begrænsede danskkundskaber havde svært ved at få et job i Danmark. Igennem IO-stillingerne kunne alle hvis førstesprog ikke var dansk, søge arbejde inden for et bredt udvalg af kommunale job. Ansøgerne skulle ifølge de officielle retningslinjer (Vejledning om integration og oplaringsstillinger, 2007) vurderes på baggrund af deres professionelle kompetencer og ikke ud fra deres danskkundskaber. Tanken bag særordningen var at eliminere sproglig konkurrence fra førstesprogsbrugere af dansk da IO-ansøgerne ikke skulle sammenlignes med ansøgere der var født og opvokset i Danmark. Uanset ansøgernes danskniveau var det et krav at alle IO-jobsamtaler skulle foregå på dansk. Hvis en ansøger klarede samtalen godt og blev tilbudt jobbet, blev vedkommende derudover også tilbudt et gratis kursus $i$ enten dansk eller et relevant fagområde som ansøgeren ønskede at kvalificere sig yderligere inden for. Men selvom intentionen bag IO-stillingerne var at bringe ansøgernes faglighed i fokus (uanset deres dansksproglige udfordringer), viste det sig under interviewene at sprog i realiteten kom til at spille en afgørende rolle i udvælgelsen af kandidater. Sproglig kunnen på dansk blev for eksempel et tilbagevendende tema i såvel de fleste jobsamtaler som i de opfølgende interview (se fx Kirilova 2013).

I artiklen her diskuterer jeg hvilken rolle sprog og ideologi spiller for udvælgelsen af ansøgere $\mathrm{i}$ to jobsamtaler. Jeg tager udgangspunkt $\mathrm{i}$ Silversteins (1985) tredimensionelle syn på sprog hvor ideologi udgør en væsentlig del for forståelsen af sprogbegrebet. For at konkretisere 
samspillet mellem sprog og ideologi gennemgår jeg endvidere begreberne dorvogtning, medlemskabsforbandling og shibbolet. Med disse begreber vil jeg operationalisere den sprogideologiske ramme og analysere de inklusions- og eksklusionsprocesser som finder sted $\mathrm{i}$ interaktionen.

Artiklen falder i fem dele. Først kommer jeg ind på eksempler fra jobsamtaler hvor sproglige og kulturelle vurderinger finder sted. Jeg introducerer og eksemplificerer sprogideologi som et overordnet begreb og gennemgår begreberne dorvogtning, medlemskabsforhandling og shibbolet. Efterfølgende diskuterer jeg shibboletter i forhold til to områder: først forhandling af fælles emner som shibboletter og dernæst brug af konventionelle udtryk som shibboletter. Jeg introducerer en hypotese om at brugen af konventionelle udtryk er særligt interessant i flersproget kommunikation, og at konventionelle udtryk muligvis vil kunne fungere som succesfuld kommunikationsstrategi når andetsprogsbrugere på begynderniveau omgås med sprogbrugere på et mere avanceret sprogligt niveau. I den tredje del gennemgår jeg data og metode. I den fjerde del analyserer jeg uddrag af to jobsamtaler hvor deltagerne benytter sig af shibboletter i forhold til såvel brugen af konventionelle udtryk på dansk som forhandlingen af fælles emner. I artiklens sidste del vender jeg tilbage til den sprogideologiske ramme for at diskutere og perspektivere dataeksemplerne.

\section{VURDERINGER I ET SPROGIDEOLOGISK PERSPEKTIV}

Det overordnede formål med en jobsamtale er at finde frem til den bedste person til et givet job. Ud over at besidde viden og kompetencer inden for et fagligt område skal en ansøger også være en person som en arbejdsgiver har lyst til at have på den arbejdsplads han eller hun har ansvar for. Sprog spiller en væsentlig rolle i udvælgelsesprocessen da måden hvorpå ansøger og ansættelsesudvalg kommunikerer og positionerer sig selv og hinanden igennem sproget, er afgørende for hvem der bliver valgt til jobbet. I et omfattende studie af jobinterview i Storbritannien gør Roberts og Campbell (2006) opmærksom på at sproglig optræden og professionel kompetence ofte kobles sammen som om der var en en-til-en relation mellem måden hvorpå en ansøger interagerer med ansættelsesudvalget, og måden hvorpå en ansøger vil agere i jobbet. Interviewet bliver dermed set som en 'proxy' - altså 
noget der træder i stedet for udførelsen af selve jobbet. Proxy-tanken hviler på den antagelse at sproglig kunnen og øvrige kompetencer går hånd $\mathrm{i}$ hånd, således at ansøgere som eksempelvis har ordet $\mathrm{i}$ deres magt, også ville kunne være i stand til at udføre arbejdsopgaverne på en tilfredsstillende måde. Dansk og international forskning i jobsamtaler (Scheuer 1998, 2001, Kerekes 2003, 2006, Roberts og Campbell 2006, Kirilova 2013, Lundmann 2015) viser netop at ansøgere som bliver tilbudt et job, ofte er gode til at reflektere over de spørgsmål de får stillet. De er særligt dygtige til at italesætte sig selv positivt på en måde der opfattes som interessant og relevant såvel professionelt som personligt. Men balancen er hårfin: Hvis ansøgerne udelukkende italesætter deres faglighed, kan det blive svært for arbejdsgiverne at fornemme selve personen bag. Og hvis de fokuserer for meget på deres privatliv i jobsamtalen, kan det opfattes som 'for meget', hvilket indebærer en risiko for at arbejdsgiverne ikke tager dem alvorligt i forhold til arbejdsopgaverne. Kulturelle stereotyper kan også spille en afgørende rolle. I Kirilova og Angouri (2018) analyserer vi en jobsamtale hvor en ansøger med mellemøstlig baggrund spontant giver udtryk for sine liberale holdninger til indtagelse af alkohol og ligestilling i familien. Med denne positionering tager han afstand fra en udbredt etnisk stereotyp om muslimer, men i samtalen får denne afstandtagen den modsatte effekt på ansættelsesudvalget som i stedet begynder at fokusere på etniske forskelle. Det er svært at sige om dette var grunden til at denne ansøger ikke fik jobbet, men jeg har tidligere dokumenteret (fx Kirilova 2014) at hvis ansøgere ikke formår at indtage en ligeværdig positionering med ansættelsesudvalget, bliver de oftest fravalgt. Dette viser at måden hvorpå en person positionerer sig igennem sprogbrug, bliver koblet til forskellige forestillinger om både sprogbrug og sprogbrugere.

Netop denne sammenhæng udtrykker Silverstein (1985) i sin sociolingvistiske teori det fuldstandige faktum om sprog (the total linguistic fact). Faktum om sprog er ifølge Silverstein at sprog skal ses og analyseres tredimensionelt. De tre dimensioner er sprogstruktur, sprogbrug $i$ kontekst og ideologier om sprog, og de hænger uløseligt sammen. For at kunne forstå sprog skal vi altså forholde os til hvem der bruger sproget, hvordan det bruges, og hvilke ideologier der dannes om 
sprogbrug og sprogbrugere. Med andre ord kan vi ikke anvende og analysere sprog uden at anerkende ideologier som konstituerende for forståelsen af såvel strukturer som brug. Når mennesker intuitivt forbinder en måde at tale på (en sproglig struktur) med en bestemt social identitet, gør de det med udgangspunkt i allerede udbredte forestillinger (ideologier) om hvordan bærerne af denne identitet (sprogbrugerne) er eller burde være. Disse forestillingerne har ikke noget med sandhed at gøre - de afspejler blot opfattelser som kan være opstået i løbet af den vurderendes opvækst, skolegang eller påvirkning fra massemedier. Det at sprog peger på social betydning, kaldes indeksikalitet (Silverstein 1976, 2003). Indeksikalitet er afgørende for at mennesker kan forstå og kommunikere med hinanden i en given kontekst. I jobsamtalerne bliver den sproglige optræden indeksikalsk for måden hvorpå arbejdet i en kommende ansættelse vil blive udført netop fordi måden en ansøger taler på, kan forbindes med en bestemt medarbejderidentitet. Der sker en konstant værditilskrivning af de sproglige resurser som mennesker anvender i forskellige kontekster, og det spiller en afgørende rolle for hvordan sprog forstås, udvikles og anvendes. Et yderligere og interessant aspekt af sprogideologiske processer har Irvine og Gal (2000) beskrevet som sletning (erasure). Sletning finder sted når opfattelser der strider imod en allerede etableret (ideologisk) forståelse, slettes fra det generelle mønster. Når politikere for eksempel hævder at 'i Danmark taler man dansk', er det et eksempel på sletning. Det passer ind i en politisk ideologi om Danmark som en etsproget, danskdomineret nationalstat, men forholder sig ikke til de sproglige praksisser ude i samfundet, hvor mennesker som bekendt har adgang til og taler mange forskellige sprog. Disse sproglige praksisser bliver 'slettet' til fordel for den overordnede (politiske) ideologi.

Ideologier kan spille en rolle enten på forhånd (som en generel holdning til en bestemt kulturel gruppe) eller opstå spontant i samtalen (som resultat af en bestemt positionering). På engelsk skelner man mellem begreberne brought along, altså det der er taget med i samtalen udefra, og brought about, altså det der opstår i interaktionen igennem forhandlingsprocessen (se fx Baynham 2014). Det er svært at adskille hvilke vurderinger der bygger på en forudindtaget stereotyp (brought along), og hvilke der er opstået undervejs (brought about), men begge 
processer har betydning for måden hvorpå vi tilskriver os selv og andre identiteter, definerer normer og danner grupper.

Sprogideologi er en abstrakt størrelse som kan være vanskelig at operationalisere, men der findes en række begreber som kan anvendes for at konkretisere relationen mellem sprog og ideologi. I denne artikel ser jeg nærmere på dorvogtning, medlemskabsforhandling og shibboletter som konkrete processer og redskaber i forståelsen af den sprogideologiske dimension.

Dorvogtning (gatekeeping) relaterer sig til de til- og fravælgelsesprocesser som mennesker bliver en del af på grund af (ofte implicitte) kriterier for hensigtsmæssig sproglig, social og kulturel adfærd (se også Tranekjær 2011). Jobsamtaler, eksamener og medarbejderudviklingssamtaler er eksempler på dørvogtende situationer hvor den ene sprogbruger (som i det konkrete tilfælde har mere magt eller bestemmelseskraft) potentielt 'vogter' over den anden sprogbruger ved at tage beslutninger som har konsekvenser (positive eller negative) for ham eller hende. Begrebet dørvogtning blev introduceret i den sociolingvistiske litteratur af Erickson (1975) og er sidenhen anvendt i en række interaktionelle studier (Erickson og Shultz 1982, Gumperz 1982, 1992, Jupp \& Gumperz 1982, Roberts 1985, 2011, Komter 1991, Kirilova 2014, Tranekjær 2015). Dørvogtning finder sted i alle vurderings- og kategoriseringsprocesser, uanset kontekst og situation. Tranekjær og Kappa (2016) mener derfor at dørvogtning udfolder sig på mikroplan i selve samtalen, hvilket betyder at samtalepartnerne på skift foretager en konstant vurdering af hinanden $i$ hver ytring. I min analyse er dørvogtning et overordnet begreb som er væsentligt for forståelsen af de muligheder og begrænsninger samtalepartnerne har og får i konteksten af jobsamtalen.

Medlemskabsforbandling og medlemskabstilskrivning er processer som handler om hvordan mennesker forhandler og tilskriver hinanden forskellige kategorier, og hvordan disse kategorier indgår i en fælles sociokulturel kontekst (fx Sacks 1972, Baker 2000, Schegloff 2007, Stokoe 2012, Day 2012, Tranekjær 2015, Tranekjær og Kappa 2016). Igennem medlemskabstilskrivning kan vi forstå hvordan en specifik social kontekst er organiseret, og hvordan normer og afvigelser produceres og reproduceres inden for rammerne af denne sociale kontekst. 
Når sprogbrugere eksempelvis bliver tilskrevet medlemskab af kategorien 'andetsprogsbruger', sker der samtidigt en hierarkisk opdeling af første- over for andetsprogsbrugere. Det medvirker til at andetsprogsbrugere ofte bliver målt ud fra førstesprogsbrugeres forestillinger om sproglig korrekthed ('assumed perfection', Davies 2003). Denne medlemskabstilskrivning kan dermed have konsekvenser for de muligheder 'andetsprogsbrugere' får hvis de konsekvent underordnes 'førstesprogsbrugere'. Det vil jeg vende tilbage til i analyserne.

Shibbolet relaterer sig til såvel dørvogtning som medlemskabstilskrivning og er blevet anvendt $\mathrm{i}$ forskellige sammenhænge til at beskrive og analysere de eksklusions- og inklusionsprocesser som finder sted i sproglige vurderinger. Begrebet stammer fra hebraisk og er omtalt i Biblen (Dommerbogen 12, 4-6) hvor udtalen med enten []] eller [s] i shibbolet blev anvendt til at afgøre hvorvidt en person tilhørte gruppen af henholdsvis gileaditter og efraimitter som på det tidspunkt lå i krig med hinanden. I den bibelske fortælling blev de personer der ikke kunne udtale shibbolet på samme måde som gileaditterne, identificeret som fjender og slået ihjel. Tanken om at en persons tilhørsforhold vurderes ud fra bestemte sproglige træk, er højaktuel i eksempelvis asylsamtaler (Blommaert 2008, 2009, Spotti 2015, Kolinksy 2016), naturalisationsog statsborgerskabssamtaler (Fogtmann 2007, McNamara 2005, Khan \& McNamara 2017) og andre former for dørvogtende interaktioner (Erickson og Shultz 1982, Tranekjær 2015).

I denne artikel anvender jeg shibbolet $i$ tråd med den sociolingvistiske litteratur, altså som et indeks for sprogligt og kulturelt tilhørsforhold til en bestemt gruppe og med en bestemt effekt ( $f x$ inklusion eller eksklusion). Brugen af enkelte fonemer, morfemer, ord, fraser eller diskurser kan fungere som shibboletter, men de forskellige sproglige niveauer (fonologisk, morfologisk, semantisk, diskursiv) hvor shibboletter kan optræde, er ofte umulige at adskille. For at et bestemt sprogligt udtryk eller en udtalevariant kan opfattes som shibbolet, skal den kunne anvendes i den rette situation og relation. Shibboletter er netop et udtryk for Silversteins tredimensionelle syn på sprog - de skal have en bestemt sproglig struktur som sprogbrugerne skal kunne identificere dem ud fra, og en specifik kontekst som de kan optræde i. Genrer og diskurser kan også fungere som shibboletter, således at en bestemt 
samtalestil eller diskurs kan associeres med en bestemt gruppe som for eksempel kan opfattes som dannet og raffineret (se fx Silversten 2006 om 'wine talk') fordi det sprog gruppen anvender, bliver indeksikalsk for besiddelsen af et bestemt kulturel kapital (Bourdieu 1977). Forskellige normer inden for samtalestil og pragmatik kan dermed komme i vejen for et vellykket samarbejde og på den måde stemple bestemte personer eller grupper som problematiske eller utroværdige på baggrund af en enkelt sætning. En analyse af shibboletter vil kunne konkretisere de problematiske situationer $i$ italesættelsen af specifikke fænomener (og endvidere også handlinger, betegnelser, informationer) der enten vil fungere som fælles referenceramme og inkludere samtalepartnerne eller føre til eksklusion.

I de næste afsnit ser jeg først på konventionelle udtryk som et eksempel på shibboletter og dernæst på etableringen af emnemæssige fællesskaber hvor shibboletterne kan opstå i forbindelse med forhandling af fælles referenceramme.

\section{KONVENTIONELLE UDTRYK SOM SHIBBOLETTER}

Jeg bruger betegnelsen konventionelle udtryk om relativt korte fraser med nogenlunde fast struktur (fonetisk, morfologisk, syntaktisk). Det kunne eksempelvis være fraser såsom 'det er i orden' eller 'helt sikkert'. Denne definition er relativ bred, men mit udgangspunkt er ikke at præcisere og afgrænse terminologien, men at fokusere på hvad der sker når sprogbrugere anvender udtryk som de kan genkende som konventionelle. Wray (2002) leverer en glimrende oversigt over formularer og konventionelle udtryk, men som hun selv pointerer, er konventionelle udtryk svære at kategorisere fordi der er mange undtagelser og overlap i såvel deres struktur som i deres funktioner. Fælles for udtrykkene er dog at de typisk er højfrekvente, umiddelbart genkendelige for førstesprogsbrugere, og at de understøtter det sociale aspekt i kommunikationen. Disse tre aspekter fokuserer jeg også på i mine analyser.

I andetsprogsundervisning med fokus på kommunikativ kompetence er indlæringen af konventionelle udtryk noget af det første nye sprogbrugere præsenteres for (Ellis 1983, Bardovi-Harlig 2012, Eskildsen og Wagner 2015). Konventionelle udtryk kan derfor betegnes som en slags pålidelighedsoer (Dechert 1983) eller sikkeerbedszoner 
(Boers m.fl. 2006) som på den ene side aflaster den kognitive byrde som andetsprogsindlæringen indebærer (Schmitt 2010), og på den anden side signalerer både sproglig og kulturel tilknytning til målsproget (Tannen 1990). Hos en nybegynder kan de konventionelle udtryk opfattes som 'markeret' sprogbrug (Eskildsen og Wagner 2015). Det betyder at hvis en sprogbruger hører et konventionelt udtryk ytret af en nybegynder, vil vedkommende formentligt lægge mærke til det $\mathrm{i}$ højere grad end hvis udtrykket blev ytret af en avanceret sprogbruger fordi det simpelthen er mindre forventeligt. I en undersøgelse af kommunikativ kompetence hos andetsprogsbrugere af engelsk gør Yorio (1980) opmærksom på at brugen af konventionelle former (som han kalder dem) tjener en række sociolingvistiske funktioner som for eksempel at afhjælpe ubekvemme eller ubehagelige øjeblikke i kommunikative situationer hvor samtalepartnernes sproglige resurser viser sig at være begrænsede:

\footnotetext{
Conventionalized forms make communication more orderly because they are regulatory in nature. They organize reactions and facilitate choices, thus reducing the complexity of communicative exchanges. They are group identifying. They separate those who belong from those who do not. They do this by serving as instruments for establishing rapport, reinforcing awareness of group membership, perpetuating goals, values, and norms of the group, indicating speakers' readiness to conform to group norms, and defining social relations and the relative status of the different communicators. (Yorio 1980:438)
}

Denne tilgang til konventionelle udtryk og deres funktioner illustrerer også vurderingsaspektet $\mathrm{i}$ interaktionen mellem første- og andetsprogstalere. For at kunne blive vurderet positivt i forhold til at være én 'vi' gerne vil have iblandt 'os' (som er kernen i den institutionelle dørvogtning), skal det være muligt for en person at forhandle et tilhørsforhold til gruppen han eller hun søger accept hos. For en andetsprogsbruger med begrænsede dansksproglige resurser kan anvendelsen af et konventionelt udtryk i samtalen hjælpe med at sikre forstålse, opbygge en relation til samtalepartneren og ikke mindst fungere som adgang til medlemskategorien 'dansk'. Det er naturligvis ikke givet at en andetsprogsbruger automatisk får anerkendelse i et kulturelt fællesskab 
alene ved at bruge konventionelle udtryk, men min hypotese er at der er noget på spil i de situationer hvor andetsprogsbrugere - især på begynderniveau - kommunikerer ved hjælp af konventionelle udtryk. I analysen vil jeg se på hvordan de konventionelle udtryk kommer til at fungere som shibboletter i forhold til at pege på et sprogligt og kulturelt fællesskab mellem samtalepartnerne. Forhandling af medlemskab er en kompleks proces som i høj grad kræver pragmatisk kompetence til at navigere i både konteksten, situationen og rollerne i samtalen. Det behandler jeg i næste afsnit.

\section{EMNEMÆSSIGE FÆLLESSKABER SOM SHIBBOLETTER}

Erickson og Shultz (1982) peger på at fælles baggrund, oplevelser og interesser i mange tilfælde vil gøre det nemmere for samtalepartnerne at finde frem til en fælles referenceramme som vil kunne bidrage til et vellykket samarbejde. Erickson og Shultz anvender også termen sam-medlemskab (co-membership) som betegnelse for det interaktionelle samarbejde. De argumenterer for at dørvogtningsprocessen $i$ al institutionel kommunikation handler om tildeling af medlemskab. Dette medlemskab er ikke nødvendigvis givet på forhånd, men det kan opstå i løbet af samtalen. Det kan være lettere at demonstrere - og lettere at forstå - at deltagerne er i gang med et samarbejde hvis de har fælles baggrund. Men det kan også gå den anden vej hvis et uønsket medlemskab til en bestemt kategori (fx køn, alder eller etnicitet) automatisk bliver tilskrevet en deltager. Når et medlemskab bliver forhandlet på plads, opstår det som Erikson og Shultz (1982) kalder samtaleharmoni (interactive synchrony) eller behagelige ojeblikeke (comfortable moments). Samtaleharmoni finder sted blandt andet fordi vi er i stand til at navigere mellem forskellige roller i samtalen - det ene øjeblik er vi lyttere, det andet øjeblik er vi talere (Goffman 1981). Disse skift udføres uden at vi tænker over dem - det er en del af reglerne for samtalen at vi hele tiden tilpasser os hinanden. Et vellykket samarbejde har netop betydning for hvem der accepteres som medlem. Stokes og Hewitt (1976: 838) ser samarbejdet som en måde hvorpå samtalepartnerne kan genoprette eventuel ubalance, afhjælpe misforståelser og foregribe uvidenhed eller ubekvemhed i samtalen. På denne måde minder Stokes og Hewitts tilgang om Yorios (1980) beskrivelse af de konventionelle 
udtryks funktion i 'problematiske situationer'. I tråd med Yorio ser Stokes og Hewitt (1976) det konversationelle samarbejde ('alignment' som de kalder det) som en mulighed for at overkomme generelle vanskeligheder i samtalen (dog uden særligt fokus på andetsprogsbrugeren). De udtrykker det således:

\begin{abstract}
[alignments are] (1)argely verbal efforts to restore or assure meaningful interaction in the face of problematic situations of one kind or another, activities such as disclaiming, requesting and giving accounts, constructing quasi-theoretical explanations of problematic situations, offering apologies, formulating the definition of a situation, and talking about motives illustrate a dual process of alignment (...) aligning actions can be shown to play a major part in sustaining a relationship between culture and conduct, in maintaining an alignment between the two in the face of actions that depart from cultural expectations or definitions of what is situationally appropriate. (Stokes og Hewitt 1976: 838)
\end{abstract}

Med denne definition berører Stokes og Hewitt forholdet mellem på den ene side kultur, som de definerer bredt som tanker, ideer og følelser som er genkendelige for medlemmerne af et givet fællesskab (Stokes og Hewitt 1976: 843), og på den anden side adford (conduct), som ifølge dem er håndteringen af de fælles tanker, ideer, følelser og måder at være på. Hvis adfard og kultur ikke stemmer overens, kan det give udfordringer i samarbejdet om at opretholde balancen. Uoverensstemmelser kan opstå hvis bestemte handlinger, herunder handlinger udtrykt gennem sprog, afviger fra ens kulturelle forventninger om hvad der er passende i en situation. Det illustrerede jeg tidligere med eksemplet om den jobansøger som fremhævede sin liberale holdning til alkohol og æateskab fordi han ville tage afstand fra en stereotyp om muslimske mænd som afholdende og kvindeundertrykkende (Kirilova og Angouri 2018). Ansøgerens adfærd og ansættelsesudvalgets opfattelser af hvad der var kulturelt passende at fremhæve, skabte netop en ubalance i samtalen som var svær at reparere. Dermed blev det uadskillelige forhold mellem sprog og ideologi i kommunikationen også tydeliggjort. 


\section{DATA OG METODE}

Eksemplerne som jeg analyserer i denne artikel, stammer fra lydoptagelser af IO-jobsamtaler, indsamlet i forbindelse med mit ph.d.-projekt (Kirilova 2013). Hele datakorpusset bestod af 41 jobsamtaler til ni forskellige jobtyper samt efterfølgende interview med 41 ansøgere og seks ansættelsesudvalg. Alle jobsamtaler og interview fandt sted i København og omegn. I denne artikel analyserer jeg samtaleuddrag af to jobsamtaler med ansøgerne Hannah og Ruben (navnene er pseudonymer). De to jobsamtaler er udvalgt dels fordi de er karakteristiske for hvordan en succesfuld jobsamtale forløber ( $\mathrm{fx}$ i forhold til struktur og emner), dels fordi jeg vil illustrere to forskellige måder at anvende shibboletter på. I jobsamtalen med Hannah er det forhandlingen af fælles interesseemner som fungerer som shibboletter og dermed muliggør tilskrivningen af et 'dansk' medlemskab. I samtalen med Ruben er brugen af konventionelle udtryk særlig interessant idet udtrykkene både peger på et fælles medlemskab og samtidig fungerer som succesfuld kommunikationsstrategi på begynderniveau. For en god ordens skyld vil jeg eksplicitere at formålet med analysen ikke er at sammenligne ansøgerne med hinanden. For komparative analyser af kandidater henviser jeg til Kirilova $(2014,2017)$. Mit mål her er først og fremmest at illustrere og analysere samarbejdet ud fra et sprogideologisk perspektiv med fokus på shibboletter og medlemskab. Jeg vil desuden diskutere hvilke kommunikative resurser og strategier der viser sig at være succesfulde i den konkrete situation, og hvordan situationen (som jeg beskrev som brought about) spiller sammen med ansættelsesudvalgenes forhåndsviden (brought along) i den generelle vurdering af jobansøgeren. Jeg anvender en analysemetode hvor jeg henter inspiration fra både den interaktionelle sociolingvistik (Gumperz, Roberts og Jupp 1979, Gumperz og Roberts 1991, Gumperz 1999, Roberts og Campbell 2006) hvor der er blevet gennemført en række lignende analyser af flersprogede jobsamtaler, og konversationsanalysen (Sacks, Schegloff og Jefferson 1974, Pomerantz 1984, Heritage 1984, Steensig 2001, Emmertsen og Heinemann 2010) hvorfra jeg benytter tekniske begreber og værktøjer i forhold til at udføre en samtaleanalyse. For at kunne vurdere hvordan de enkelte samtalebidrag opfattes og forhandles af bidragsyderne, ser jeg på såvel den sekventielle turtagning som på det 
suprasegmentale niveau ( $\mathrm{fx}$ tryk, intonation, pauser) og endvidere også på paralingvistiske elementer (fx latter, mumlen).

Fælles for den interaktionelle sociolingvistik og konversationsanalysen er at begge tilgange indtager deltagernes perspektiv $i$ analysen. Men hvor konversationsanalysen betragter samtalen som autonom og i princippet uafhængig af begivenheder uden for samtalen, er en sociolingvistisk tilgang typisk mere åben for fortolkning i et bredere samfundsperspektiv. Eftersom jeg vil fokusere på det sprogideologiske element i kommunikationen og dørvogtningsprocessen i det hele taget, vil jeg også inddrage data fra de interview som jeg gennemførte med ansættelsesudvalgene umiddelbart efter jobsamtalerne. Her kom lederne af ansættelsesudvalgene med forklaringer på hvorfor de havde valgt en bestemt ansøger frem for en anden. Disse data giver dermed et yderligere forklaringsperspektiv som bidrager til forstålsen af analyserne. Igennem eksempler fra disse forskellige interaktioner kan jeg vise både et kontekstualiseret interaktivt samarbejde hvor jeg tager udgangspunkt i deltagernes interaktionelle resurser, og en mere dekontekstualiseret ideologisk opfattelse (selvfølgelig kun baseret på udtalelserne om de to jobkandidater) af hvad ansættelsesudvalgene mener er godt eller dårligt dansk.

\section{HANNAH}

Hannah er en 38-årig kvinde som er født og opvokset i Holland. Hun er uddannet apoteker. På interviewtidspunktet havde Hannah tilbragt et år i Danmark og var gået i gang med at lære dansk. Hannah søgte et job som receptionist på et forvaltningskontor i København. Jobsamtalen varede 19 minutter. Ansættelsesudvalget bestod af fire personer: en kvindelig leder, en kvindelig medarbejder, en mandlig IT-medarbejder en kvindelig HR-medarbejder. Der var i alt tre ansøgere som blev indkaldt til samtale, og det var Hannah der fik tilbudt jobbet.

Jeg vil præsentere tre korte uddrag af Hannahs jobsamtale. I det første eksempel deltager lederen (LED), en medarbejder (MED) og Hannah (HAN). Uddraget nedenunder begynder med Hannahs svar på lederens spørgsmål om hvad kun godt kan lide at lave i sin fritid. 
Eksempel 1. Hannah (begynder ved 14:09)

1 HAN: ø:h jeg kan godt lide at læ:se <MED: mmh>

2 me:n øh kun når jeg e:r hvad er det

3 ø:h hvor jeg ha- har ikke så mange po-xxx

4 hvor kan du sige $\uparrow$ det hvor siger man det (.)

5 hvor det ikke så har det ikke så (.) ptravlt

6 MED: ja <LED: ja> ja <HAN: ja>

7 HAN: så jeg må væ:re

8 MED: ja

9 HAN: ikke så stressed [engelsk udtale] (.)ha ha

10 <LED: mmh mmh> <MED: ja ja>

11 men jeg kan godt l- øh li' det og øh også

12 øh in begyndelsen her ø:h var jeg på: øh ø:h

13 hvad er det $\varnothing: \mathrm{hm} \varnothing \mathrm{h}$ (1.5)

14 hvad $\uparrow$ hedder det nu $\varnothing: \mathrm{h}$ pila:tes

15 LED: ja <MED: ja> ja <MED: ja> <HAN: ja>

16 MED: ja <HAN: ha ha

17 LED: det kender vi godt

18 HAN : o-kay haha

Uddraget illustrerer først og fremmest at Hannah har svært ved at finde ord på dansk (fx linje 2-5 og igen i linje 11-15). Der er flere eksempler på fyldte pauser, tøven, selv-reparatur samt grammatiske og fonologiske afvigelser karakteristiske for sprogbrug på begynderstadie. Hannah bruger metasprog som strategi til at fremkalde de ord hun leder efter (fx linje 5 og linje 14), og det lykkes hende at finde frem til 'travlt' og 'pilates' hvorefter der etableres forståelse, hvilket ansættelsesudvalget bekræfter med 'ja' og 'mhm'. Når Hannah nævner at hun godt kan lide at dyrke pilates, responderer lederen med 'det kender vi godt' der både fungerer som en bekræftelse af det sagte og samtidig etablerer et fællesskab omkring Hannahs interesse. Ved at bruge flertalsformen 'vi' opretter lederen et 'os'-fællesskab hvor hun inkluderer ikke kun sig selv, men også de andre medlemmer i udvalget. Det vil jeg vende tilbage til efter at jeg har præsenteret de andre to eksempler.

Deltagerne i eksempel 2 er lederen (LED), medarbejderen (MED), en IT-medarbejder (ITM) og Hannah. 


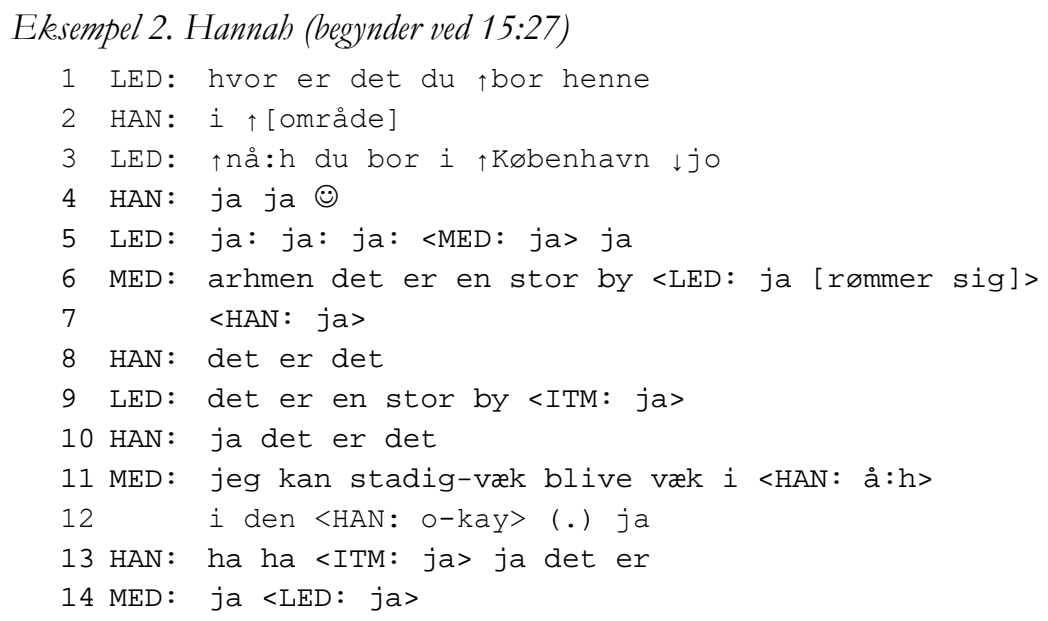

I eksempel 2 spørger lederen Hannah hvor hun bor. Da Hannah nævner et bykvarter i København, reagerer lederen straks ved $\uparrow$ nå:h du bor i $\uparrow$ København $\downarrow$ jo (linje 3). Partiklen 'nå' er en epistemisk skiftemarkør (Nielsen 2002, Heinemann 2016) som markerer ændring i forhold til informationstilstanden (eller 'change of state', fx Heritage 1984, Emmertsen og Heinemann 2010). Det signalerer at den information som bliver introduceret i den forrige tur (linje 2) har været ukendt eller overraskende for samtalepartneren (lederen) som efterfølgende har ændret sin opfattelse af enten emnet eller samtalepartneren som har introduceret emnet. Vi ser desuden en kraftigt stigende og faldende intonation i denne ytring. Når Hannah bekræfter den nye information i linje 4, påbegynder forhandlingen af affiliering (eller en måde at udvise tilknytning på) hvor alle deltagere i samtalen kommer med positive bidrag. I linje 6 bygger medarbejderen videre på emnet om København ved at sige 'arhmen det er en stor by', og både Hannah, IT-medarbejderen og lederen bekræfter udsagnet enten ved direkte gentagelse ('det er en stor by ja') eller ved en pronominel opsummering ('ja det er det'). Også i resten af samtalen (linje 11-14) fortsætter affilieringen. Medarbejderen (MED) opgraderer 'arhmen det er en stor by' til 'jeg kan stadigvak blive væk i den' (se fx Pomerantz 1984 om 'assessments'). Turudvekslingen understøtter her primært den fatiske del af kommunikationen og har til formål at bekræfte og anerkende hinandens bidrag. Det er et 
eksempel på et behageligt ojeblik (Erickson og Shultz 1982) hvor samtalepartnerne netop har forhandlet fælles medlemskab på plads og er $\mathrm{i}$ gang med at anerkende hinanden for det. Italesættelsen af byområdet i København fungerer her som shibbolet der synliggør en fælles referenceramme og åbner dermed op for en interesse $i$ at finde frem til andre emner deltagerne kunne have tilfælles. Samtidig begynder en affilieringsproces som alle medlemmer af ansættelsesudvalget deltager i, og som gradvist fører til godkendelsen af Hannah i et 'os-fællesskab'. Lad os se på endnu et eksempel hvor lederen spørger Hannah om hun har familie i Danmark og derigennem finder ud af at Hannah har en dansk kæreste. I linje 1 svarer Hannah nemlig at hun har svigerfamilie i Jylland:

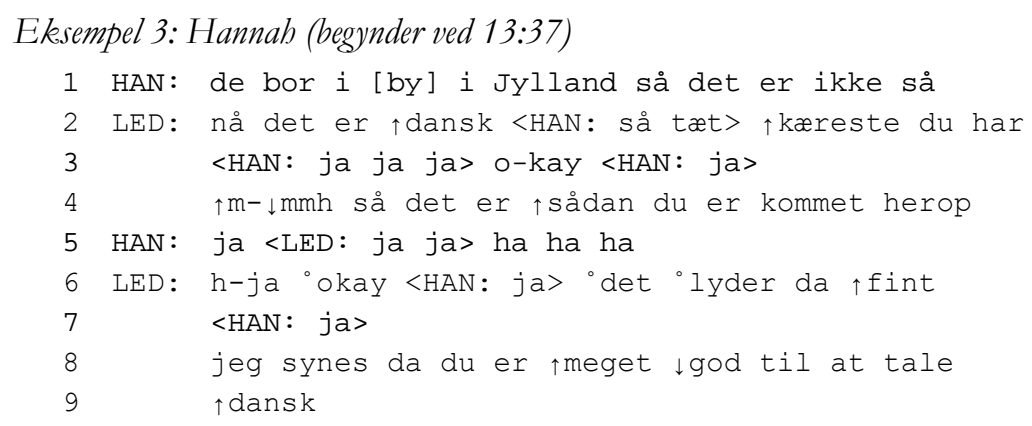

Når Hannah har fortalt at hendes svigerfamilie bor $i$ en by $i$ Jylland, reagerer lederen også med den epistemiske skiftemarkør 'nå' idet hun finder ud af at Hannah har en dansk kæreste, og at det må være derfor hun er flyttet til Danmark. Medlemskabet der etableres i eksempel 3, sker på baggrund af det nyintroducerede emne 'dansk kæreste'. Brugen af 'nå' er her parallelt til det vi så i eksempel 2, hvor lederen på samme vis reagerer på at Hannah bor i København. Efter at Hannah i linje 3 bekræfter det som lederen netop har fundet ud af, fortsætter samarbejdet igennem latter og gensidige anerkendelser. Lederen kommer for eksempel med to positive vurderinger: først siger hun at det lyder fint at Hannah er kommet til Danmark på grund af sin danske kæreste, og dernæst komplimenterer hun Hannah for at være meget god til at tale dansk. Den positive udvikling i samarbejdet kommer også til udtryk 
gennem lederens hurtige tempo, smilestemme, turinitiativer samt hendes intonation og tryk på de ytringer som anerkender medlemskabet,

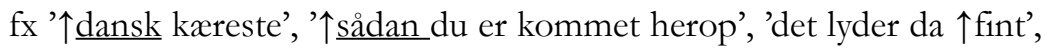
'du er $\uparrow$ meget $\downarrow$ god til at tale $\uparrow$ dansk'. Med alle disse bidrag udviser lederen ikke blot interesse, men også i høj grad en anerkendelse af at Hannah på disse punkter udviser medlemsskab af det sprogkulturelle fællesskab som lederen selv er en del af.

Jeg vil nu træde ud af samtalekonteksten og anskue denne udtalelse $i$ en bredere sammenhæng hvor jeg henter information fra det interview som jeg gennemførte med lederen efter at jobsamtalen var blevet afviklet. Interviewets formål var for mig at få kendskab til lederens (og i det hele taget ansættelsesudvalgets) ræsonnement bag udvælgelsen af kandidater. For at kunne nå frem til dette spurgte jeg blandt andet om udvalgets vurdering af kandidaternes evne til at tale og forstå dansk. Umiddelbart efter jobinterviewet mente lederen at Hannah var 'den dårligste til dansk' blandt de $\mathrm{i}$ alt tre ansøgere til receptionistjobbet. Jeg gennemførte et lille vurderingseksperiment hvor jeg bad lederen, HR-medarbejderen og de øvrige to tilstedeværende medlemmer om at give Hannah point som ifølge dem indikerede hvor god hun var til dansk på en skala fra 1 (som stod for 'ubehjælpsom') til 5 (som stod for 'perfekt'). Vurderingsskalaen var ikke tænkt som en objektiv fremstilling af Hannahs kompetencer i dansk, men netop en subjektiv commonsense-holdning til kandidaternes sprogkunnen. Hannah fik 2 point fra tre af udvalgets medlemmer og 2,5 point fra et af medlemmerne (det gav 2,125 i gennemsnit). Til sammenligning fik de andre to ansøgere 3,25 og 2,875 i gennemsnit - deres danskkompetencer fik altså en mere positiv vurdering end Hannahs. Selv om jeg reelt set ikke ved hvad ansættelsesudvalget forholder sig til når de vurderer hvorvidt ansøgerne er 'gode' eller 'dårlige' til dansk, giver disse tal dog et indblik i udvalgets holdninger til Hannahs kompetencer i dansk. Det er derfor interessant at diskutere uoverensstemmelsen mellem vurderingen $\mathrm{i}$ det afsluttende interview og lederens udtalelse i eksempel 3 hvor hun komplimenterer Hannah for at være 'meget god' til dansk. Hvad handler denne ros om? Handler den om sprogkompetence? Jeg viste $\mathrm{i}$ alle tre eksempler at Hannah formår at forhandle sig frem til en positionering i os-gruppen. Italesættelsen af pilates, boligen i Kø- 
benhavn, den danske kæreste og svigerfamilie kunne netop være de genkendelige adgangsgivende shibboletter som får lederen og medarbejderen til at reagere positivt og bekræftende. Shibboletterne her kunne også fungere som en sikkerhed i forhold til at Hannah formentlig vil blive boende i København og dermed er en pålidelig ansøger. Selv om disse shibboletter kunne siges at være bragt tilfældigt ind i samtalen, spiller de ikke desto mindre en rolle i forhandlingen af en fælles referenceramme og dermed også tilskrivningen af et 'dansk' medlemskab. Det hjælper Hannah at positionere sig som én ansættelsesudvalget har en række identiteter tilfælles med, og derfor er hun muligvis at foretrække frem for andre ansøgere. De emnemæssige fællesskaber bliver her indeksikalske for det at være 'god nok' til jobbet, og når Hannah tilskrives en plads i os-medlemskabet (her forstået som det arbejdsgiverne forestiller sig som 'dansk'), vurderes hun også som 'god til dansk'. 'God til dansk' kan samtidigt også betyde at Hannah anerkendes som medlem på et dybere niveau. Ud fra Irvine og Gals (2000) sletning som jeg beskrev i artiklens teoretiske del, bliver os-tilhørsforholdet så stærkt etableret at de områder som ikke passer ind i mønsteret slettes. Der bliver dermed ikke lagt mærke til eventuelle sproglige afvigelser, mangler og misforståelser idet en-af-os-ideologien i det tilfælde ser ud til at fremstå vigtigere for arbejdsgiverne end det at være flydende i dansk.

\section{RUBEN}

Ruben er en 25-årig mand som er født og opvokset i Cuba hvor han er uddannet inden for teater. Han havde boet i Danmark i et år på optagelsestidspunktet og var begyndt at tage danskkurser i mellemtiden. Ruben søgte et job som køkkenmedhjælper på en skole for børn med autisme. Jobsamtalen varede 31 minutter. Ansættelsesudvalget bestod af to personer: en kvindelig leder (LED) og en kvindelig medarbejder (MED). Der var i alt fire ansøgere som blev indkaldt til samtale, og det var Ruben der fik tilbudt jobbet.

Jeg vil her præsentere tre korte uddrag af Rubens jobsamtale. I det første eksempel nævner Ruben at han godt kan lide at spille guitar og fortæller i øvrigt om sine fremtidsplaner. 
Eksempel 4: Ruben (begynder ved 05:21)

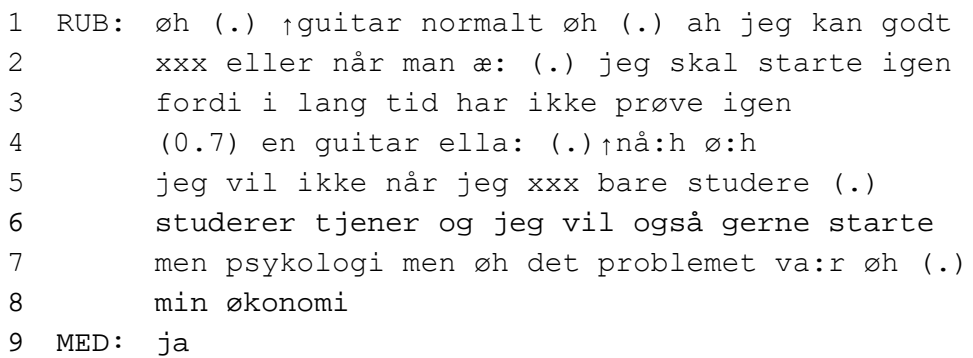

Selv om transskriptionen her gør det nemmere at følge med i Rubens narrativ i sammenligning med hvordan han optræder i jobsamtalen, er det vigtigt at tage i betragtning at Rubens udtale på dansk såvel som de mange pauser og tøven gør det vanskeligt at forstå ham. Fraværet af løbende minimalrespons fra ansættelsesudvalget betragter jeg som et tegn på at medarbejderen og lederen lytter intenst og forsøger at skabe mening i Rubens forklaring. Der kommer nemlig ingen lydlig respons i 24 sekunder $^{1}$, selv om Rubens mange pauser og tøven kan fungere som relevante turovergangssteder hvor ansættelsesudvalget kunne have udført reparatur eller kommet med en kort bekræftelse - de koncentrerer sig i stedet om at forstå hvad Ruben siger. I linje 6-8 sker der pludseligt et forståelsesmæssigt gennembrud da Ruben ytrer 'jeg vil også gerne starte men psykologi men problemet var min økonomi', og det reagerer medarbejderen straks på ('ja', linje 9). Ytringen er den første i uddraget som ikke består af afbrudte fraser, men beskriver et kausalt forløb som giver mening i forhold til medarbejderens spørgsmål om Rubens planer for fremtiden. Dette eksempel har jeg taget for at illustrere hvordan Ruben kommunikerer når han bliver bedt om at svare på et spørgsmål, og det vil jeg vende tilbage til. Lad os nu se på de sekvenser hvor det primært er medarbejderen og lederen der taler, mens Ruben lytter. I eksempel 5 forklarer lederen hvordan skolen som Ruben har søgt job på, er organiseret, og hvor mange børn der går på skolen.

1 Videodata ville selvfølgelig have givet et bedre billede af eventuelle kropssprogsreaktioner. 
Eksempel 5: Ruben (begynder ved 01:42)

1 MED: og i heroppe $\uparrow$ bor tolv $\uparrow$ børn

2 RUB: ja-

3 MED: -hvo:r der bor seks børn $i \uparrow$ dne:n ende af huset

$4 \quad<$ RUB: okay> og seks børn $i \downarrow$ dnanden ende

5 RUB: o-kay

6 MED: og $i$ hver ende er der en $\uparrow$ gruppe.mor

7 RUB: $0-\uparrow k a y$

8 MED: lissom en mor eller far derhjemme-

9 RUB: det er helt $i$ orden

10 LED: ha ha

I dette eksempel producerer Ruben fem forskellige slags feedback. Vi ser en løbende opgradering af feedbackformerne - fra en mere generisk minimalrespons ('ja') i starten af uddraget til et konventionelt udtryk ('det er helt i orden') i slutningen. I linje 2 bekræfter han medarbejderens ytring med et 'ja'; i linje 4 overlapper han medarbejderen med et kort og hurtigt 'okay'; i linje 5 kommer han med et længere 'o:kay', og i linje 7 producerer han et endnu længere og trykstærkt 'o: $\uparrow \underline{k a: y '}$ med en tydeligt opadgående intonation. Det andet og tredje 'okay' lyder nærmest overdrevet på grund af forlængelsen og intonationen. De falder også en smule før det relevante turskift. Den femte feedback ('det er helt i orden') i linje 9 kommer også pludseligt og udløser en dæmpet latter fra lederen i linje 10. Overordnet set udviser Ruben både en god kontrol over samtalen og en aktiv lytteforståelse for samtaleemnet. Jeg vil nu fokusere på brugen af udtrykket 'det er helt i orden'. Funktionsmæssigt anvendes 'det er helt i orden' på dansk primært for at bekræfte samtalepartneren og vise vedkommende at det, der tales om, er blevet opfattet positivt. 'Det er helt i orden' er et idiom på dansk fordi 'i orden' i denne betydning ikke har noget med 'orden' at gøre, men udelukkende er et udtryk for at det der siges, er acceptabelt, og at der ikke er noget at indvende. Udtrykket optræder typisk efter enten en kommisiv (jeg vil bede dig om x) eller en interrogativ der søger bekræftelse (skal vi ikke gøre y). Personen der siger 'det er helt i orden' har accepteret det som den anden person har bedt om eller foreslået. Der ligger også en hierarkisk relation i godkendelsen, således at personen der siger 'det er helt i orden' i princippet har en højere status 
eller større beslutningskraft end sin samtalepartner og dermed også lov til at godkende det der er blevet foreslået eller spurgt om. Rubens 'det er helt i orden' i linje 10 falder en smule skxvt i forhold til rollerne i samtalen idet medarbejderen ikke søger tilladelse, men er i gang med en narrativ. På den anden side fremstår 'det er helt i orden' som en opgradering af den tidligere feedback som Ruben har produceret $i$

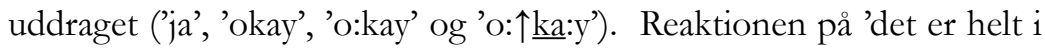
orden' er latter - lederen og medarbejderen har lagt mærke til udtrykket som de formentligt opfatter som morsomt, muligvis på grund af den hierarkiske skævhed. Men selv om det rammer skævt (eller måske netop derfor), skaber udtrykket mulighed for gensidig tilknytning. Når Ruben anvender et specifikt og kontekstafhængigt konventionelt udtryk på dansk og samtidig udviser høj samtaleteknisk og pragmatisk forståelse, er lederen og medarbejderens reaktioner positive. Lad os se på et lignende eksempel:

Eksempel 6: Ruben (begynder ved 01:01)

1 LED: kunne du bare spise $\uparrow$ chokolade som du $\uparrow v i l l e$

11 RUB: ja

12 LED: $\uparrow j a$

13 RUB: ja helt sikkert

14 LED: ha ha

15 RUB: ja masse af chokolade

Eksempel 6 handler om Rubens tidligere arbejde på en chokoladefabrik. Når lederen spørger Ruben om han kunne spise chokolade som han ville, svarer Ruben først 'ja' og derefter producerer han to udtryk som jeg har karakteriseret som konventionelle: 'helt sikkert' og 'masser af chokolade'. Disse udtryk har ligesom i eksempel 5 en understøttende funktion i forhold til lederens spørgsmål og bemærkninger. På nøjagtig samme måde som vi så i det forrige eksempel, griner lederen efter udtrykket 'helt sikkert'. Om lederen griner af situationen (det gode ved at spise chokolade hver dag) eller af Rubens brug af selve udtrykket, er usikkert, men det er vigtigt at forstå turudvekslingen og latteren som kommunikative handlinger der styrker relationen mellem ansættelsesudvalget og Ruben. Dette er et eksempel på fatisk kommunikation, også kaldet 'the bonding function of language' (Senft 1995) 
hvis formål ikke er at udveksle information, men at understøtte samarbejdet. De betydninger der bliver udvekslet, er ikke referentielle, men netop indeksikalske og handler om deltagernes gensidige positioneringer (Laver 1975).

I løbet af den 31 minutter lange jobsamtale anvender Ruben en række udtryk til at understøtte den fatiske kommunikation, og denne brug er bemærkelsesværdig i sammenligning med andre ansøgere hvis samtaler jeg tidligere har analyseret (fx Kirilova 2013). Jeg oplister de udtryk som jeg har kategoriseret som konventionelle:

1. det er rigtig svært

2. helt sikkert

3. ja precis

4. den er god

5. det er spændende

6. det er helt i orden

7. hårdt arbejde

8. det er god træning

9. jeg er træt af chokolade

10. det var en dejlig samtale

11. helt vildt forfærdeligt

12. vildt irriterende hele tiden

13. jeg kan godt lide grill

14. traditioner - det er dejligt

15. nåh - dejligt

16. ikke nogen problem

17. jeg elsker hest

De fleste af udtrykkene er hyppigt anvendt på dansk (fx 1-7) og kan genkendes som fraser ( $\mathrm{fx}$ 'jeg er træt af X', 'jeg kan godt lide X'). 'Jeg elsker hest' og 'ikke nogen problem' afviger fra standarddansk, men jeg har alligevel taget dem med. 'Jeg elsker hest' passer for eksempel ind i formularen 'jeg elsker $\mathrm{x}+$ ubestemt', og 'ikke nogen problem' indeholder en kongruensafvigelse som man i hurtig tale næppe lægger mærke til. Fælles for de 17 udtryk er at de er korte, genkendelige og understøtter den fatiske kommunikation. I kontrast til eksempel 4 som 
illustrerede Rubens danskkompetence i noget der minder om monologisk tale, kan vi se at brugen af konventionelle udtryk i dialogisk tale hjælper Ruben med at fremstå som en mere sikker sprogbruger. Udtrykkene tjener som 'sikkerhedszoner' (Boers m.fl. 2006) og 'pålidelighedsøer' (Deckert 1984). De fleste udtryk indeholder også en personlig vurdering ('det er svært', 'det er dejligt', 'den er god', 'vildt irriterende') som ud over at bekræfte de ytringer medlemmerne af ansættelsesudvalget kommer med, positionerer Ruben som en medarbejder der markerer sine personlige holdninger og nemt tager stilling til forskellige emner. For ansættelsesudvalget er det oplagt at se udtrykkene som indeksikalske for måden hvorpå han vil kunne udføre arbejdsopgaverne i selve jobbet: selvstændigt, kritisk og engageret.

Jeg vil nu inddrage ansættelsesudvalgets kommentarer om Ruben $i$ afslutningsinterviewet. Interviewet blev gennemført af min kollega Eva Wedervang-Jensen. Da Eva spurgte lederen om de havde fundet en kandidat som de gerne ville ansætte, svarede lederen at udvalget havde valgt Ruben fordi han 'passer ind i miljøet' og var 'nem at kommunikere med på trods af det danske'. I interviewet beskrev lederen de tre andre kandidater som henholdsvis 'flydende', 'meget akademisk' og 'god til dansk'. Ruben blev ikke umiddelbart vurderet som særlig god til dansk. Det er derfor interessant at se på dobbeltheden i lederens holdning. På den ene side giver hun udtryk for at Ruben er nem at kommunikere med, men på den anden side mener hun at det sker 'på trods af det danske'. Når hun betegner Ruben som én der er nem at kommunikere med, er det muligvis med udgangspunkt $i$ hans interaktionelle kompetencer, for eksempel aktiv lytning, forståelse for pragmatik, fatisk kommunikation og brug af konventionelle udtryk. Det peger på en kontekstualiseret (samtalebaseret) forståelse for kommunikation hvor interaktionel kompetence vurderes højt. Når lederen til gengæld nævner at den 'nemme' kommunikation sker 'på trods af det danske', får vi indblik i et dekontekstualiseret ideologisk syn på Rubens danskkompetencer der i givet fald ikke er 'gode'. Men fordi Ruben er i stand til at forhandle medlemskab igennem blandt andet brugen af konventionelle udtryk, formår han muligvis at positionere sig som én der med lederens ord 'passer ind i miljøet', én af os. Fordi Ruben er blevet accepteret som 'en af os', slettes - ligesom i tilfældet med 
Hannah - de afvigelser og misforståelser der ikke passer ind i ideologien om 'korrekt' dansk. For Ruben er anvendelsen af konventionelle udtryk endvidere en succesfuld strategi fordi udtrykkene kan pege på at han allerede tidligere har været en del af et fællesskab hvor disse udtryk anvendes, eller at han har arbejdet målrettet på at tilegne sig dem. At gøre sig umage med at lære dansk på kort tid var noget mange af ansættelsesudvalgene vægtede højt blandt ansøgerne (Kirilova 2013).

\section{KONKLUSION}

I denne artikel har jeg analyseret to jobsamtaler fra et integrationsinitiativ målrettet ansøgere der taler dansk som andetsprog. Med udgangspunkt $\mathrm{i}$ interaktionsanalyse har jeg set nærmere på hvilken rolle sprog og ideologi spiller når ansøgere udvælges til jobbet. For at operationalisere forholdet mellem sprog, kultur og ideologi har jeg anvendt begrebet shibbolet som et indeks for sprogligt og kulturelt tilhørsforhold til en bestemt gruppe. Jeg har beskrevet og eksemplificeret shibboletterne i forhold til to områder: først, forhandling af fælles emner som shibboletter og dernæst brugen af konventionelle udtryk som shibboletter. Mine analyser viser at hvis både jobansøgere og ansættelsesudvalg er $\mathrm{i}$ stand til at forhandle og etablere et momentant fællesskab som ansøgeren kan placere sig i, bliver ansøgeren også vurderet som egnet til det ansøgte job. Medlemskabet forhandles på det kulturelle plan, men det sker via sprog som resurse.

Brugen af konventionelle udtryk som shibboletter i medlemskabstilskrivninger er særlig interessant. Selv om jeg kun har en enkelt samtale at gå ud fra, har jeg forsøgt at illustrere at konventionelle udtryk understøtter den fatiske kommunikation mellem samtalepartnerne, og det spiller muligvis en rolle for såvel sproglig som kulturel anerkendelse af den tosprogede samtalepartner. Mens førstesprogsbrugere af dansk vil kunne anvende konventionelle udtryk mere eller mindre ubemærket, udløser udtrykkene en 'markeret' effekt når de anvendes af andetsprogsbrugere (jf. Eskildsen 2009). Det sker blandt andet fordi udtrykkene for det meste optræder uventet $i$ et ordforråd på begynderniveau. Det kræver givetvis mere data at undersøge forskellige sprogbrugeres anvendelse af konventionelle udtryk og deres effekt på modtageren, men det er min hypotese at der er noget på spil når konventionelle 
udtryk optræder hyppigt i flersprogede samtaler. Forholdet mellem brugen af bestemte fraser, ord eller diskurser og kulturel anerkendelse er oplagt at undersøge videre $i$ andre typer flersproget interaktion hvor institutionel dørvogtning har en betydning for samtalens dynamik og udfald.

Marta Kirilova

Institut for Nordiske Studier og Sprogvidenskab

Københavns Universitet

mki@hum.ku.dk

\section{UDSKRIFTSNØGLE}

\begin{tabular}{|c|c|}
\hline (.) & kort pause \\
\hline$(4.0)$ & pause på 4 sekunder \\
\hline$<$ hallo $>$ & overlap \\
\hline HALLO & høj stemme \\
\hline 'hallo & lav stemme \\
\hline ha:llo & vokalforlængelse \\
\hline †hallo & opadgående intonation \\
\hline$\downarrow$ hallo & nedadgående intonation \\
\hline hh & ind- eller udånding \\
\hline (;) & smilestemme \\
\hline$x x x$ & uforståeligt ord/frase \\
\hline ?hallo? & usikkerhed/gæt \\
\hline
\end{tabular}




\section{LITTERATUR}

Baker, C.D. 2000. Locating culture in action: Membership categorisation in texts and talk. St. Leonards, NSW: Allen \& Unwin.

Bardovi-Harlig, K. 2012. Formulas, routines, and conventional expressions in pragmatics research. ARAL 32. 206-227.

Baynham, M. 2014. Identity: Brought about or brought along? Narrative as a privileged site for researching intercultural identities. F. Dervin \& K. Risager (red.), Researching identity and interculturality, 73-92. New York: Routledge.

Blommaert, J. 2008. Language, asylum, and the national order. Current Anthropology 50(4). 415-441.

Blommaert, J. 2009. Investigating narrative inequality: African asylum seekers' stories in Belgium. Discourse \& Society 12(4). 413-449.

Boers, F., J. Eyckmans, J. Kappel, H. Stengers, \& M. Demecheleer. 2006. Formulaic sequences and perceived oral proficiency: Putting a lexical approach to the test. Language Teaching Research 10(3). 245-261

Bourdieu, P. 1977. Cultural reproduction and social reproduction. J. Karabel \& A. H. Halsey (red.), Power and ideology in education, 487-511. New York: Oxford University Press.

Davies, A. 2003. The native speaker: Myth and reality. Clevedon: Multilingual Matters.

Day, D. 2012. Conversation analysis and membership categories. The encyclopedia of applied linguistics. John Wiley \& Sons. https://doi.org/10.1002/9781405198431. wbeal0211

Dechert, H.W. 1983. How a story is done in a second language. Strategies in interlanguage communication. C. Faerch \& G. Kasper (red.), Strategies in interlanguage communication, 175-195. London: Longman.

Ellis, R. 1983. Formulaic speech in early classroom second language development. Handscombe, D. (red.), The question of control. Selected papers from the 17th annual convention of teachers of English to speakers of other languages (TESOL, Toronto, Canada, March 15-20, 1983), 53-65

Emmertsen, S. \& T. Heinemann. 2010. Realization as a device for remedying problems of affiliation in interaction. Research on Language and Social Interaction 43(2). 109132.

Erickson, F. 1975. Gatekeeping and the melting pot: Interaction in counseling encounters. Harvard educational review 45(1). 44-70.

Erickson, F. \& J. Shultz. 1982. The counselor as gatekeeper: Social interaction in interviews. New York: Academic Press. 
Eskildsen, S.W. 2009. Constructing another language: Usage-based linguistics in second language acquisition. Applied Linguistics 30(3). 335-357.

Eskildsen, S.W. \& J. Wagner. 2015. Sprogbrugsbaseret læring i en tosproget hverdag. En forskningsoversigt over sprogbrugsbaseret andetsprogstilegnelse og sprogpædagogiske implikationer. NyS, Nydanske Sprogstudier 48. 71-104.

Fogtmann, C. 2007. Samtaler med politiet: interaktionsanalytiske studier af sprogtestning $i$ danske naturalisationssamtaler. Ph.d.-afhandling. Københavns Universitet.

Goffman, E. 1981. Forms of talk. Oxford: Blackwell.

Gumperz, J.J., C. Roberts \& T.C. Jupp. 1979. Crosstalk: a study of cross-cultural communication, London: National Centre for Industrial Language Training in association with BBC.

Gumperz, J. J. 1982. Discourse strategies. Cambridge: Cambridge University Press.

Gumperz, J.J. \& C. Roberts. 1991. Understanding in intercultural encounters. J. Blommaert \& J.J. Verschueren (red.), The pragmatics of intercultural and international communication, 51-90. Amsterdam: John Benjamins.

Gumperz, J.J. 1992. Interviewing in intercultural situations. P. Drew \& J. Heritage (red.), Talk at Work, 302-327. Cambridge: Cambridge University Press.

Gumperz, J. 1999. On interactional sociolinguistic method. S. Sarangi \& C. Roberts (red.), Talk, work and institutional order: Discourse in medical, mediation and management settings, 453-471. Berlin: Mouton de Gruyter.

Heinemann, T. 2016. Registering revision: The reduplicated Danish change-of-state token nå. Discourse Studies 18(1). 44-63.

Heritage, J. 1984. A change-of-state token and aspects of its sequential placement. J.M. Atkinson \& J. Heritage (red.), Structures of social action, 299-345. Cambridge, England: Cambridge University Press.

Irvine, J.T. \& S. Gal. 2000. Language ideology and linguistic differentiation. P. Kroskrity (red.), Regimes of language, 35-83, Santa Fe, NM: School of American Research Press.

Jupp, T.C., \& J. Gumperz. 1982. Language and disadvantage: the hidden process. J. Gumperz (red.), Language and social identity, 232-256. Cambridge: Cambridge University Press.

Kerekes, J. 2003. Distrust: A determining factor in the outcomes of gatekeeping encounters. G. House, G. Kasper \& S. Ross (red.), Misunderstanding in Social Life, 227-257. Harlow Pearson Education Limited.

Kerekes, J.A. 2006. Winning an interviewer's trust in a gatekeeping encounter. Language in Society 35(1). 27-59. 
Khan, K., \& T. McNamara. 2017. Citizenship, immigration laws, and language. S. Canagarajah (red.), The Routledge handbook of migration and language, 451-467. London: Routledge.

Kirilova, M. 2013. All dressed up and nowhere to go: Linguistic, cultural and ideological aspects of job interviews with second language speakers of Danish. Ph.d.-afhandling, Københavns Universitet.

Kirilova, M. 2014. 'Det kan være svært' - om sprog og kultur i andetsprogsdanske ansættelsessamtaler. Nordand - Nordisk tidsskrift for andetsprogsforskning 9(1). 11-4.

Kirilova, M. 2017. 'Oh it's a DANISH boyfriend you've got'- co-membership and cultural fluency in job interviews with minority background applicants in Denmark. J. Angouri, M. Marra \& J. Holmes (red.), Negotiating boundaries at work, 29-49. Edinburgh: Edinburgh University Press.

Kirilova, M. \& J. Angouri. 2018. You are now one of us - negotiating 'fitting in' in the workplace. A. Creese \& A. Blackledge (red.), The Routledge handbook of language and superdiversity, 345-360. London: Routledge.

Kolinsky, H. 2016. The shibboleth of discretion: The discretion, identity, and persecution paradigm in American and Australian LGBT asylum claims. Berkeley Journal of Gender Law \& Justice 31(2). 206-240.

Komter, M. 1991. Conflict and Co-operation in job interviews. Amsterdam: John Benjamins. Laver, J. 1975. Communicative functions of phatic communion. A. Kendon, R. Harris, M. Key (red.), Organization of behavior in face-to-face interaction, 215-238. The Hague: World Anthropology, De Gruyter.

Lundmann, L. 2015. Basic assumptions when assessing people: Studies of job interviews and personality testing. Ph.d.-afhandling. Det samfundsvidenskabelige fakultet, Københavns Universitet.

McNamara, T. 2005. 21st century shibboleth: Language tests, identity and intergroup conflict. Language Policy 4(4). 351-370.

Nielsen, M.F. 2002. Nå! En skiftemarkør med mange funktioner. Studier i Nordisk 20002001. 51-67. København: Selskab for Nordisk Filologi.

Pomerantz, A. 1984. Agreeing and disagreeing with assessments: Some features of preferred/dispreferred turn shapes. J.M. Atkinson \& J. Heritage (red.), Structures of social action, 57-101. Cambridge, England: Cambridge University Press.

Roberts, C. 1985. The interview game: and how it's played: British Broadcasting Corporation.

Roberts, C. 2011. Gatekeeping discourse in employment interviews. C. Candlin \& S. Sarangi (red.), Handbook of communication in organisations and professions, 407-432. Mouton de Gruyter. 
Roberts, C. \& S. Campbell. 2006. Talk on trial. Research report 344, London: Department for Work and Pensions (DWP) http://www.researchonline.org.uk/sds/search/download.do;jsessionid=C6E7B6F8A4A55F73A94896710AE0996?ref=B1568 (21.10.2018).

Sacks, H. 1972. An initial investigation of the usability of conversational data for doing sociology. D. Sudnow (red.), Studies in Social Interaction, 31-74. New York: Free Press.

Sacks, H., E.A. Schegloff \& G. Jefferson. 1974. A simplest systematics for the organisation of turn-taking for conversation. Language 50. 696-735.

Schegloff, E.A. 2007. A tutorial on membership categorization. Journal of pragmatics 39(3). 462-482.

Scheuer, J. 1998. Den umulige samtale: sprog, kon og magt i jobsamtaler. København: Akademisk forlag.

Scheuer, J. 2001. Recontextualisation and communicative styles in job interviews. Discourse Studies 3. 223-248.

Schmitt, N. 2010. Researching vocabulary: A vocabulary research manual. Berlin: Springer.

Senft, G. 1995. Phatic communion. J. Verschueren, J.O. Östman \& J. Blommaert (red.), Handbook of pragmatics, 226-223. Amsterdam: John Benjamins.New

Silverstein, M.1976. Shifters, linguistic categories, and cultural description. K. Basso \& H. Selby (red.), Meaning in anthropology, 11-55. Albuquerque: University of New Mexico Press.

Silverstein, M. 1985. Language and the culture of gender: at the intersection of structure, usage, and ideology. E. Mertz \& R.J. Parmentier (red.), Semiotic mediation: Sociocultural and psychological perspectives, 219-259. Orlando, FL: Academic Press.

Silverstein, M. 2003. Indexical order and the dialectics of sociolinguistic life. Language \& communication 23(3-4). 193-229.

Silverstein, M. 2006. Old wine, new ethnographic lexicography. Annual Review Anthropology 35. 481-496.

Spotti, M. 2015. Sociolinguistic shibboleths at the institutional gate. K.K. Arnaut, J. Blommaert, B. Rampton \& M. Spotti (red.), Language and superdiversity, 261-279. New York: Routledge.

Steensig, J. 2001. Sprog i virkeligheden. Bidrag til en interaktionel lingvistik. Århus: Aarhus Universitetsforlag.

Stokes, R. \& J.P. Hewitt. 1976. Aligning actions. American Sociological Review, 41. 838-849.

Stokoe, E. 2012. Moving forward with membership categorization analysis: Methods for systematic analysis. Discourse Studies 14(3). 277-303. 
Tannen, D. 1990. Gender differences in topical coherence: Creating involvement in best friends' talk. Discourse Processes 13(1). 73-90.

Tranekjær, L. 2011. I praktik som dansker. Nordand - Nordisk tidsskrift for andetsprogsforskning 6(1). 7-35.

Tranekjær, L. 2015. Interactional categorization and gatekeeping: Institutional encounters with otherness. Bristol: Multilingual Matters.

Tranekjær, L. \& Kappa, K. 2016. The interactional establishment of the membership category 'nonnative speaker' in gatekeeping encounters. K. Bardovi-Harlig \& J.C. Félix-Brasdefer (red.), Pragmatics and Language Learning 4. 93 -122.

Vejledning om integration og oplaringsstillinger. 2007. Udgivet af KL, Danske Regioner og KTO Kommunale Tjenestemænd og Overenskomstansatte, https://www. kl.dk/ImageVaultFiles/id_33506/cf_202/Vejledning_om_integrationsog_ oplringsstillinger.PDF (Tilgået 21. september 2018).

Wray, A. 2002. Formulaic sequences and the lexicon. Cambridge: Cambridge University Press.

Yorio, C. A. 1980. Conventionalized language forms and the development of communicative competence. TESOL Quarterly 14(4). 433-442. 